\title{
MODELUL TÂNĂRULUI ÎN OMILIILE DESPRE MACABEI ALE SÂNTULUI IOAN GURĂ DE AUR
}

\author{
Remus Onişor ${ }^{*}$
}

\begin{abstract}
The model of a young man in John Chrysostom's Homilies on the Maccabees. The custom of reciting a panegyric at the celebration of a MartyrSaint was also an occasion for the religious community to reunite. In his sermons on the Maccabean martyrs, Saint John Chrysostom finds sufficient motives in their way of life to guide and advise the young Christians of his time. The predecessors and the heroes of faith represent a constant example of life for those who live in the midst of so many challenges. The youth of today may wonder how they can keep their faith in a world that tries to deny or discredit it. The connection point between yesterday and today is the sincere belief, the assertion of Christian values and the dignity of a healthy tradition. Saint John Chrysostom uses the example of the Maccabees martyrs as fertile ground of faith, self-control and a balanced and respectful education model. His sermon begins with an explanation of the biblical text and continues with the moral catechism of young people. Christians in Antioch from that period were proud of the glory and the faith of local ancestors. The intention of worthiness is explained in a particular way. The good example is beneficial in the lives of believers. The purpose of the sermon is to strengthen the adhesion of the listener to the values of christian tradition. The young Maccabees are noble beings, with a noble education, received from a noble mother. The mother is also an example of courage, selfcontrol and sovereign mind. The model for the young generation of today, reverberated from a biblical and patristic tradition is this: steadfastness in an ever-changing world.
\end{abstract}

Keywords: Young people, model, John Chrysostom, mother, faith, honor, steadfastness, responsibility.

\section{Preliminarii}

În majoritatea îndemnurilor făcute de către slujitorii Bisericii tinerilor, se are în vedere exemplul înaintaşilor şi dragostea pentru credinţă şi neam. Acelaşi lucru îl face şi Sfântul Ioan Gură de Aur în omiliile sale despre Martirii Macabei. Găsim acolo un răspuns religios

* $\mathrm{PhD}$, Associate Professor, Faculty of Orthodox Theology at University "1 Decembrie 1918" in Alba Iulia. 
la întrebările actuale privind valoarea şi rostul vieţii, precum şi un apel către Dumnezeu pentru cei năpăstuiţi. Exemplul primit de la înaintaşi oferă o explicaţie a identităţii noastre creştine, din perspectiva veşniciei. Cei ce cugetă, gândesc şi făptuiesc trebuie, uneori, să afle şi din exemplele biblice şi patristice cum e să trăiască în mijlocul atâtor provocări ce vin şi stăruie în viaţa Bisericii.

Sfântul Ioan Hrisostom încearcă şi reuşeşte în Omiliile despre martirii Macabei să răspundă la nişte întrebări: cum e să supravieţuieşti şi să trăiești într-o lume care încearcă să nege dreptul la credinţă, ba chiar să-l distrugă. Răspunsurile sunt coerente, iar ideile şi sentimentele - materie primă a intelectualului - ne arată şi cum a reuşit să-i înveţe, pe contemporani şi de ce nu şi pe noi, cum se pot rezolva problemele legate de credinţă, de viaţa religioasă, probleme ce nu puteau fi nici evitate şi nici amânate.

În vremurile acelea, oamenii îndurau ostilitatea, uneori murind din pricina ei, fără să poată face ceva pentru a-1 schimba pe celălalt. Sau dacă face ceva o face în ultimă instanţă, când moartea e inevitabilă, iar el rămâne model de răbdare, devotament, credinţă şi demnitate. Marele predicator creştin ne transmite în aceste Omilii o învăţătură care străbate veacurile şi devine mereu actuală, deşi contextul şi istoria mult s-au schimbat. Trebuie să învăţăm că e datoria, mai ales a celor tineri, să încerce să producă o schimbare în atitudinea celui indiferent, necredincios, nepăsător şi autonom.

Punctul de legătură între ceea ce a fost atunci şi ceea ce este astăzi, este definit şi exprimat de termenul integrare. Iar aceasta o facem prin credinţa serioasă şi prin afirmarea valorilor creştine tradiţionale, care conferă şi echilibru şi demnitate şi valoare.

Tinerii de ieri şi de azi caută să afle de ce trăiesc şi cum trebuie să-şi afirme credinţa primită de la înaintaşi, de la Biserica din care fac parte.

Ei, ca tineri au dreptul la o viaţă interioară împreună cu Dumnezeu? Ce înseamnă a fi sfânt? Cum să-L cunosc pe Dumnezeu? Ce crede El despre mine? Sfinţii Părinţi ne mai pot învăţa ceva? 
Biserica mai are un mesaj actual pentru noi, care trăim în alte împrejurări şi cu alte provocări decât părinţii noştri?

Exemplele biblice şi patristice au întotdeauna darul de a ne convinge.

\section{Marele predicator creștin şi cetatea sa}

Antiohia (Siriei) a fost al treilea oraş ca importanţă al Imperiului Roman ${ }^{1}$. Marea metropolă a Orientului Apropiat ${ }^{2}$, situată la aproximativ $500 \mathrm{~km}$. N de Ierusalim, a fost întemeiată de către Seleucus I Nicator († 281 î.d.H.) în jurul anului 300 î.d.H. ${ }^{3}$ Aici adepţii lui Hristos au primit pentru prima dată numele de creştini ${ }^{4}$ (F.Ap. 11,26).

Populaţia Antiohiei a fost întotdeauna amestecată, iar istoricul evreu Iosif Flaviu precizează că Seleucizii i-au încurajat pe evrei să vină în acest oraş, acordându-le „drepturi depline de cetăţenie"5. Seleucizii şi romanii ${ }^{6}$ au ridicat aici temple mărețe şi clădiri impunătoare ${ }^{7}$, iar mai târziu alţi conducători au întemeiat şcoli de

${ }^{1}$ Capitala Imperiului, Roma şi marele oraş egiptean Alexandria ocupau primele două locuri (v. G. Downey, A History of Antioch in Syria: From Seleucus to the Arab Conquest, Princeton, New York, 1962).

2 În prezent oraşul se numeşte Antakya şi se află pe teritoriul Turciei (v. Dicţionar Biblic, Oradea, Edit. Cartea Creştină, 1995, p. 51).

${ }^{3}$ Cetatea siriană a fost cea mai importantă dintre cele 16 Antiohii întemeiate de Seleucus în onoarea tatălui său (Ibidem).

${ }^{4}$ Folosirea acestui nume atesta faptul că la Antiohia ,poporul creştin”, pentru prima dată a fost văzut ca o sectă dizidentă de iudaism (v. R.E. Brown, A. Fitzmyer, R.E. Murphy, Introducere şi comentariu la Sfânta Scriptură, vol. VIII, Edit. Galaxia Gutemberg, 2007, p. 611).

${ }^{5}$ Flavius Josephus, Antichităţi iudaice, 2, Bucureşti, Edit. Hasefer, 2001, XII, III, 1, p. 76.

${ }^{6}$ Antiohia a căzut în anul 64 î.d.Hr. în mâinile generalului roman Pompei (v. A.J. Festugière, Antioche païenne et chrètienne. Libanius, Chrysostome et les moines de Syrie, Paris, Edit. de Baccard, 1959, p. 17 u.).

${ }^{7}$ Oraşul număra în epoca romană o populaţie de aproximativ 500.000 de locuitori (v. G. Downey, A History ...). 
retorică, biblioteci şi biserici. Din aceste motive oraşul Antiohia a fost numit „Parisul secolului al IV-lea”, pentru splendoarea arhitecturală şi „Viena secolului al IV-lea”, pentru cultura sa ${ }^{8}$. Sfântul Apostol Pavel a avut strânse legături cu Antiohia. De această cetate sunt legate primele semne ale creşterii episcopatului monarhic, model care va deveni predominant în lumea creştină. Renumitul episcop martir ,Sfântul Ignatie ,se plângea de faptul că, Biserica de aici, era încercată de ereticii care negau realitatea izbăvitoare a Patimilor şi a morţii lui Hristos $^{9}$, şi implicit faptul că Iisus a fost o fiinţă trupească ${ }^{10}$.

Unul din primii şi cei mai influenţi teologi-episcopi din Antiohia a fost Teofil, care a scris tratatul său Către Autolic $(\text { aproximativ } 180)^{11}$. El este printre primii care încearcă să elaboreze o teologie trinitară şi un sistem de exegeză în cadrul unei apologii publice, pentru credinţa creştină. Nu ezită să se folosească de învăţ̧ătura iudeoelenistică a Logosului, de exegeza, morala şi apologetica iudaismului $^{12}$.

${ }^{8}$ v. Ierom. Policarp Pîrvuloiu, Introducere la Sf. Ioan Gură de Aur. Predici la sărbători împărăteşti şi Cuvântare de laudă la sfinţi, ediţia a II-a, col. P.S.B., 14, nr. 2, Bucureşti, Edit. Basilica, 2015, p. 9.

${ }^{9}$ S-a discutat mult pentru a se stabili dacă Sfântul Ignatie Teoforul combate, în epistolele sale, o singură tendinţă, în care s-ar uni dochetismul şi practicile iudaice, sau două. Sunt unii teologi care vorbesc şi de o a treia, în care predicatori itineranţi contestă funcţia episcopală (v. Claudio Moreschini, Enrico Norelli, Istoria literaturii creştine vechi greceşti şi latine, I, Iaşi, Edit. Polirom, 2001, p. 125-129.

10 Această învăţătură dochetistă a determinat o replică puternică din partea Sfầntului Ignatie, care a generat în gândirea patristică un larg proces, menit să evidenţieze realitatea şi caracterul sacramental al întrupării lui Hristos (v. E. Decrept, Le paix de l'Eglise d'Antioche d'apres les Lettres ignatiennes, Revue des Sciences Religieuses, nr. 83(2), 2009, p. 201-207).

${ }^{11}$ Din această lucrare reiese că Biserica antiohiană era încă puternic influenţată de curentele intelectuale iudaice (v. C. Moreschini, E. Noreli, Istoria literaturii ..., I, p. 232-234).

12 v. N. Zeegers, Les trois cultures de Théophile d'Antioche, în B. Pouderon, J. Doré (ed.) Les apologistes chrétiens et la culture grecque, Paris, Edit. Beauchesne, 1998 (Theologie Historique, 105, p. 135-176). 
În această perioadă a sosit în oraş gânditorul encratit ${ }^{13}$ Tation care va colaţiona textele evanghelice în lucrarea sa celebră Diatessaron $^{14}$. El apare ca un propovăduit plin de pasiune pentru multe segmente de creștini, vorbitor de siriacă ${ }^{15}$ din Biserica antiohiană ${ }^{16}$.

În timpul persecuţiei lui Decius $(249-251)^{17}$ a fost martirizat aici celebrul episcop Vavila, iar după restabilirea păcii, monumentul său a devenit un important loc de pelerinaj pentru creştini ${ }^{18}$. Episcopul martir Vavila reprezintă, în ochii antiohienilor, pe cel ce spune adevărul şi are curajul de a-l înfrunta pe împărat, dar şi forţa calmă, venită din puterea de a-şi stăpâni patimile ${ }^{19}$. În anul 350 moaştele sale au fost mutate în cartierul Daphne, lângă un izvor ce avea un caracter sacru. În rândul creştinilor s-a răspândit credinţa că eşecul împăratului Iulian Apostatul din războiul împotriva perşilor s-a datorat Sfântului Vavila ${ }^{20}$.

Din Omiliile Sfântului Ioan Gură de Aur reiese că la Antiohia exista „un complex de comunităţi pline de viaţă "21. În oraş se va

${ }^{13}$ v. Encratism - encratit în Pr. J.A. McGuckin, Dicţionar de teologie patristică, Iaşi, Edit. Doxologia, 2014, p. 144-145.

14 v. W. L. Petersen, Tatian's Diatessaron, Its Creation, Dissemination, Significance and History, în Scholarship, Brill, Leiden, 1994.

15 In perioada patristică Antiohia a fost un oraş bilingv: se vorbea greaca şi siriaca.

16 v. E. Norelli, La critique du pluralisme grec dans le Discours aux grecs de Tatien, în B. Pouderon, J. Doré (ed.), Les apologistes ..., p. 81-120.

17 J.B. Rives, Decree of Decius and the Religion of Empire, Journal of Roman Studies, 89, 1999, p. 135-144.

18 v. Sf. Ioan Gură de Aur, Cuvântare la Sf. sfinţitul Mucenic Vavila, în PSB, 14, p. 319-384.

19 v. M.F. Baslez, Persecuţiile în antichitate, Bucureşti, Edit. Artemis, 2009, p. 191.

20 Împăratul Iulian ar fi insultat memoria sfântului, când a dispus ca moaştele acestuia să fie îndepărtate din vecinătatea templului lui Apollo, deoarece ,zeul încetase să mai vorbească". Creştinii susţineau că Sfântul Vavila îl adusese la tăcere pe demonul Apollo, în timp ce păgânii din Antiohia spuneau că Apollo fusese ofensat de aşezarea rămăşiţelor pământeşti a unui muritor lângă templul său (v. Daniel Buda, Creştinii şi păgânii în Antiohia sec. II-IV, Cluj-Napoca, Pressa Universitară Clujeană, 2014, p. 159 u. şi 174 u.).

${ }^{21}$ J.A. McGuckin, Dicţionar ..., p. 21. 
construi o biserică monumentală, de formă octogonală, cu rol de catedrală. Pe atunci era una din cele mai mari biserici ale lumii creştine. Antiohia $^{22}$, bogată în bani şi în cultură, păgână şi creştină, era locul de baştină al Sfântului Ioan Gură de Aur.

\section{Eroii Macabei}

În anul 168 î.d.H. în spaţiul evreiesc se produce un eveniment inedit, ce va constitui un şoc pentru iudaismul epocii ${ }^{23}$. Pentru prima dată un popor a fost împiedicat să-şi practice religia strămoşească, iar acest lucru a dus la declanşarea unui război, al evreilor împotriva ocupantului sirian ${ }^{24}$. Este aşa-numita criză macabeeană, după numele eroului ei Iuda Macabeul. La Ierusalim şi în diaspora, criza macabeeană a produs o literatură de propagandă, în scopul atribuirii unui caracter exemplar evenimentelor şi personajelor implicate în ele.

Cartea 1 şi 2 Macabei dezvoltă tematica „morţii eficiente" 25 , într-un proces de rezistenţă activă. Catalizatorul luptei de eliberare a fost execuţia unor fiinţe inocente, luptători fără arme şi victime civile bătrâni, mame şi copiii - care sunt singurii reprezentaţi în martirologia macabeeană ${ }^{26}$. Dacă pentru greci, supliciile care însoțesc execuţiile dezumanizează victima, o smulg din mijlocul comunităţii şi îi şterg amintirea din memoria colectivă, pentru evrei moartea martirilor e una paradoxală, deoarece cel credincios ,este socotit între fiii lui Dumnezeu şi partea lui între sfinţi”, iar el va fi răsplătit de însuşi „,Domnul cel Atotputernic”, care îi va da „cununa cea strălucitoare” (Înţelep. lui Solomon, 5,5,15,16).

22 Potrivit Sfântului Ioan, Antiohia era formată din 10\% bogaţi, 10\% săraci, iar restul de $80 \%$ din clase medii (v. Ierom. P. Pîrvuloiu, op.cit., p. 10, 21-4).

${ }^{23}$ v. M.F. Baslez, Persecuţiile ..., p. 117.

${ }^{24}$ V. P. Schäfer, Judéophobie. Atitudes à l'egard des Juifs dans le monde antique, Paris, Edit. Cerf, 2003.

${ }^{25}$ v. M. F. Baslez, Persecuţiile ..., p. 134.

$26 \mathrm{Ch}$. Batsch, La Guerre et les rites de guerre dans le judaïsme du deuxième Temple, Supplements to the Journal for the Study of Judaism 93, Leyde, 2005, p. 263-264. 
În orice societate şi în orice cultură apare întrebarea multiplă: de ce trebuie să suferim?, care este sensul încercărilor?, de ce murim şi ce se întâmplă după?, care este deci sensul vieţii?. În acest sens, relatările despre martiri, atât în spaţiul iudaic, cât şi în cel creştinesc, relevă elaborarea unei antropologii şi a unui sistem de valori care contestă modelul elinesc ${ }^{27}$.

În literatura macabeeană, speranţa învierii - învierea trupurilor era de neconceput pentru elini - este legată de experienţa persecuţiei. Cartea 2 Macabei este în chip special preocupată de moartea martirilor şi acest fapt hrăneşte speranţa în înviere, cel puţin în istoria celor şapte fraţi martiri. Cel care moare pentru Lege are speranţa nestrămutată, că „Dumnezeu îl va învia cu înviere de viaţă veşnică” $(2 \mathrm{Mac} .7,9)^{28}$. Sunt credincioşi hrăniţi cu speranţa în înviere, care vor fi capabili să dea martiri într-un lung şir de persecuţii.

Cartea 2 Macabei consideră martiriul o „,conduită eroică” şi un „exemplu de nobleţe” pentru tineretul naţiunii sale, deoarece se va continua ,într-un memorial al valorii”, adică va rămâne un model, nu numai în amintirea tinerilor, ci şi în aceea a tuturor credincioşilor unei comunităţ̧i ${ }^{29}$. Şi mama celor şapte fraţi Macabei este menită să supraviețuiască ,eroic” în memoria colectivă (2 Mac. 6, 28, 31; 7, 20). Eroizarea celor şapte fraţi şi a mamei lor este materializată printr-un monument comemorativ în Antiohia, lucru pe care îl menţionează şi asupra căruia se oprește, în Omiliile sale, Sfântul Ioan Gură de Aur, antiohian prin naştere şi prin cultură. Mucenici Macabei au murit eroic ,în numele valorii lor" ${ }^{30}$. Povestea celor şapte fraţi Macabei şi a mamei lor vor găsi în creştinătatea din Antiohia un teren fertil.

\footnotetext{
${ }^{27}$ v. G. Gnoli, J.P. Vernaut (ed.), La Mort, les morts dans les sociétés anciennes, Cambridge University Press, Cambridge, Paris, 1982, p. 44-76. Vezi şi J.P. Vernaut, Le Mort hérö̈que chez les grecs, Nantes, Edit. Pleins Feux, 2001.

${ }^{28}$ v. O. Mainville, D. Marguerat (dir.) Résurrection. L'après mort dans le monde ancien et le Nouveau Testament, Genève-Montreal, Edit. Labor et Fides, 2001, p. 45-72.

${ }^{29}$ v. M.F. Baslez, Persecuţiile ..., p. 159.

${ }^{30}$ Ibidem.
} 
Sfântul Ioan Gură de Aur foloseşte imaginea celor şapte fraţi ca exemplu de fermitate în credinţă, de stăpânire a trupului de către suflet, de model de educaţie şi care într-un anume fel prefigurează Biserica.

Atunci când suporți greutăţile şi provocările acestei vieţi, o faci pentru Dumnezeu, urmând modelul lui Hristos; nu trebuie să provoci autoritățile, din orice moment istoric sau context special, ci trebuie să păstrezi o conduită echilibrată şi respectuoasă.

\section{Intenţia de onorabilitate la marele orator antiohian}

Sfântul Ioan Gură de Aur a rostit două Omilii despre Macabei $^{31}$, la Antiohia, reluând apoi tema, într-o omilie despre Eleazar şi cei şapte fii, la Constantinopol ${ }^{32}$.

Alături de comentariile sale asupra întreg Vechiului şi Noului Testament, omiliile Sfântului Ioan descriu viaţa din Antiohia în derularea sa liturgică, marile evenimente şi diversitatea practicilor religioase. Anii de luptă împotriva ereticilor de toate felurile, împotriva creştinilor iudaizanţi, epoca preoţiei sale, vor fi marcaţi de dezvoltarea cultului martirilor, atestat de panegiricile sale despre sfinţii antiohieni, printre care figurează şi Macabeii ${ }^{33}$. Predica sa se deschide către subiectele cele mai variate: în primul rând către explicarea textului biblic, iar apoi către catehizarea preoţilor în plan moral. De o mare însemnătate se bucură analizarea realităţii sociale a oraşului său, Antiohia $^{34}$. Predicatorul are o inspiraţie entuziastă şi sensibilă la problemele felurite, etice, spirituale, sociale şi chiar politice. Reiese,

\footnotetext{
${ }^{31}$ Le avem traduse în româneşte în Sf. Ioan Gură de Aur, Predici ... (PSB 14), p. 443-449, 450-454.

32 în Migne, P.G. 63, 523-530 (în limba franceză o găsim în Raphaëlle Ziadé, Les martyrs Macabées: de l'histoire juive au culte chrétien, Boston, Edit. Leiden, 2007, p. 333-344).

${ }^{33}$ v. C. Moreschini, E. Norelli, Istoria literaturii, II/1, Iaşi, Edit. Polirom, 2004, p. $165 \mathrm{u}$.

${ }^{34}$ Ibidem.
} 
din predica sa, fervoarea spontană a tinerilor credincioşi antiohieni, pentru gloria şi mândria locală ${ }^{35}$.

Întreg exordiu din Omilia $1^{36}$ este construit pe tema luminii: sărbătoarea Macabeilor este ziua cea mai luminoasă din $\mathrm{an}^{37}$.

În Omilia a $2-\mathrm{a}^{38}$ elogiul asupra celor şapte tineri are ca model un ,râu din care curge aurul prin şapte izvoare" ${ }^{39}$.

El face elogiul celor şapte fii care dovedesc o credinţă plină de onoare şi respect ${ }^{40}$, un model de urmat în ceea ce priveşte curajul mărturiei.

Sfântul Ioan face dovada unei voinţe pedagogice deosebite, în care intenţia de onorabilitate a credinţei unor tineri este în chip special explicată ${ }^{41}$. Şi aşteaptă de la ascultătorii săi, aşa cum îi învaţă cu multă dăruire, fructele învăţăturii sale. El face o lungă preaslăvire a capacităţii lor de înţelegere a cuvintelor pe care li le adresează. Suntem chemaţi cu toţi, credincioşi de toate vârstele, luând exemplul celor tineri „să ne ducem în luptă pregătiţi şi să dobândim bunătăţile sale cereşti'" ${ }^{\prime 2}$. Predica şi cuvântul de învăţătură trebuie să-şi găsească împlinirea în viaţa de zi cu zi a Bisericii. Exemplul bun, onorabil, are efecte benefice pentru viaţa religioasă a credincioşilor, în special a celor tineri.

Omiliile despre Macabei ale Sfântului Ioan se încadrează în genul de discurs epidectic, care are rolul de a provoca admiraţia şi emulaţia auditoriului. Vocaţia principală a acestui tip de discurs este aceea de a ranforsa adeziunea publicului la valorile creştine

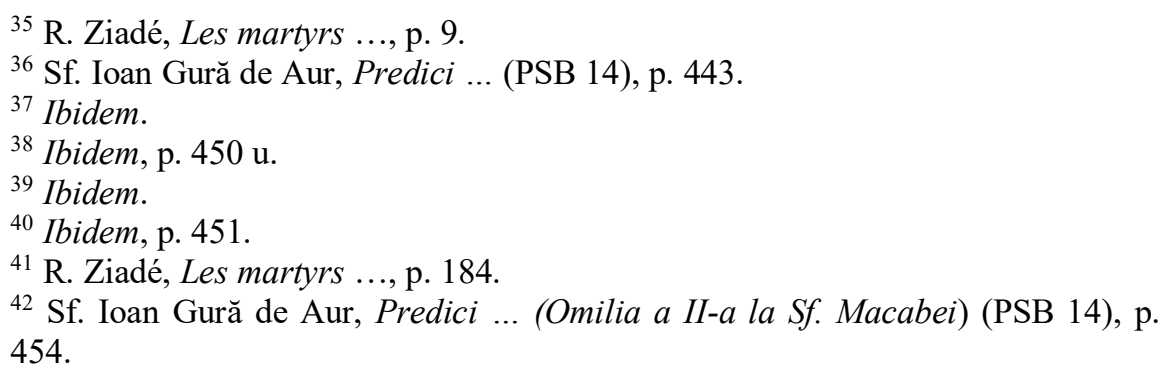


recunoscute ${ }^{43}$. Ori acţiunea socială nu poate lipsi din adunarea onorabilă, ce ascultă cuvântul şi-1 pune în practică.

Valori şi credinţe comune care dovedesc o validitate permanentă sunt evidenţiate, de marele orator creştin, cu scopul de a demonstra universalitatea exemplului tinerilor Macabei ${ }^{44}$.

Tinerii Macabei sunt caracterizaţi ca fiinţe nobile. Iată ce zice Sfântul Ioan: „Frăţeşti sunt luptele, înrudite faptele; iar unde este înrudirea de fapte, acolo nu-i nici întâiul, nici al doilea" ${ }^{45}$. Găsim aici evidenţiate nu atât rudenia trupească, materială, ci una spirituală, diferită nu prin naştere, ci prin educaţie.

\section{Mama, emulaţie şi spirit educaţional}

Mama joacă un rol important în literatura biblică posterioară Exilului. Acelaşi rol important îl joacă mama în viaţa Sfântului Ioan Gură de Aur. Se ştie foarte bine că rămânând văduvă, deşi era încă tânără, mama Sfầntului Ioan s-a dedicat, cu multă energie, creşterii şi educaţiei acestuia. A căutat să-1 dea la cei mai buni profesori ai timpului. Se ştie, de asemenea, că în secolul IV d.H., desăvârşirea creştină era considerată asceza, iar Sfântul Ioan a încercat-o şi el, dar nu imediat, ci după moartea mamei sale, pentru a nu o părăsi pe aceea care s-a jertfit pentru educaţia lui ${ }^{46}$.

În cartea 2 Macabei mama celor şapte fraţi martiri este educatoarea lor, îi exhortează şi îi încurajează constant, în încercările cu care se confruntă ${ }^{47}$. Ea îşi face cu succes datoria de a transmite, până la capăt, credinţa, aducându-le toată puterea şi milostivirea Dumnezeului creator. Iată cum o descrie Sfântul Ioan:

\footnotetext{
${ }^{43}$ v. L. Pernot, La rhetorique de l'éloge dans le monde gréco-romain, Paris, 1993, p. 719-720.

${ }^{44}$ R. Ziadé, Les martyrs ..., p. 194.

${ }^{45}$ Omilia a II-a la Sf. Macabei ..., (PSB 14), p. 451.

${ }^{46}$ v. C. Moreschini, E. Norelli, Istoria ..., II/1, p. 162.

${ }^{47}$ M.F. Baslez, Persecuţiile ..., p. 164.
} 


\section{$15^{\text {th }}$ International Simposium of Science, Theology and Arts}

„Să audă mamele aceasta! Să imite vitejia acestei femei, să imite dragostea ei de copii! Să-şi crească copiii aşa cum i-a crescut şi mama aceasta! Nu naşterea de copil o face pe o femeie mamă, că aceasta se datorează firii, ci creşterea copiilor o face pe femeie mamă. Iar asta se datorează voinţei" ${ }^{\prime 48}$.

Mama este totodată păstrătoarea tradiţiilor strămoşeşti ${ }^{49}$. Ea devine un erou, în sensul grecesc al termenului, adică ,demn de o

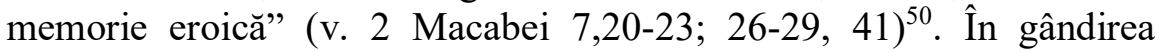
filosofică grecească femeia participă la idealul bărbătesc prin virtute şi curaj, dar aici e vorba de curajul de a sluji, în vreme ce bărbatul se identifică ,,prin curajul de a conduce" 51 .

Observăm aici o reactualizare a figurii biblice a ,femeii puternice”, femeia „cu resurse”. Aşa era concepută ea în literatura sapienţială biblică, fiind accentuată în secolul IV de Sfinţii Părinţi.Iată ce zice Sfântul Ioan Hrisostom: „Bun prilej este să îi spun mamei (...) cuvântul acela profetic care spune: «Tu eşti ca un măslin roditor în casa Domnului»»" (Ps. 51,7) ${ }^{52}$.

Mama Macabeilor devine şi ea, atât în concepţia autorului biblic cât şi a Sfinţilor Părinţi din secolul IV o figură patristică ,o mamă a neamului”; un ,dascăl al tuturor”: „Nimeni, dar, chiar de ar fi ajuns la cea mai înaltă treaptă de bărbăţie şi răbdare, să nu socotească o ruşine de a o avea ca dascăl pe această bătrână femeie""53.

Dragostea de mamă, cu toate slăbiciunile ei de femeie, datorită vârstei şi maternităţii, e caracterizată ca venind din raţiune şi stăpânire de sine, înscriindu-i sentimentele dincolo de prezent, în veşnicie:

${ }^{48}$ Omilia I la Sf. Macabei ..., Predici ..., (PSB 14), p. 447.

${ }^{49} \mathrm{v}$. R. Doran, The martyr a synoptic view of the mother and her seven sons, în G.W. Nickelsburg \& J.J. Collins, Ideal Figures in ancient Judaïsm, Society of Biblical Literature, Ann Arbor, 1980, p. 189-219.

${ }^{50}$ M.F. Baslez, Persecuţiile ..., p. 164.

${ }^{51}$ Ibidem.

${ }^{52}$ Omilia I ..., Predici..., (PSB 14), p. 448.

${ }^{53}$ Sf. Ioan Gură de Aur, Omilia a II-a la Sf. Macabei, în Predici ... (PSB 14), p. 454. 
„Pe această femeie să o imite părinţii. Pe urmele ei să meargă mamele, femeile, bărbaţii ... oricâtă filosofie am împlini în viaţă, filosofia acestei femei e cu mult mai presus ..." 54 .

Dar cu mult mai mult, chipul „Mamei Curaj" ${ }^{55}$, este acela care a impresionat cel mai mult sensibilităţile evreieşti şi creştine, chip care nu a încetat să capete noi valenţe, de-a lungul vremii ${ }^{56}$.

În primul secol al erei creştine, mama simbolizează stăpânirea sentimentelor şi suveranitatea raţiunii. De exemplu, în relatarea martirilor din Lyon în 177, Blandina este prezentată ca o ,nobilă mamă”, culme a paradoxului, deoarece era şi adolescentă şi sclavă ${ }^{57}$.

Pentru multe generaţii acest model de mamă şi exemplu de curaj al tinerilor Macabei va crea un sistem de valori de mare anvergură duhovnicească pentru viaţa Bisericii.

\section{De la cultul martirilor la mediatizarea valorilor}

Evrei pioşi, Macabeii au acceptat supliciul şi moartea fără să protesteze, fiind convinşi că vor fi răsplătiţi în viaţa de apoi. Această speranţă se prezintă ca o cheie, ce permite înţelegerea fenomenului extraordinar al încercărilor din viaţă şi care vor fi exploatate în chip pozitiv de Sfântul Ioan Gură de Aur şi de alţi Sfinţi Părinţi: „Ea (mama) nu se uita la pământ, ci la toate bunătăţile ce li se pregăteau" "58. Curajul de a înfrunta suferinţa îi este alimentat de speranţa vie şi de nezdruncinat: „Veselă şi plină de curaj, a pornit la luptă cu multă

\section{${ }^{54}$ Ibidem.}

${ }_{55}^{55}$ M.F. Baslez, Persecuţiile ..., p. 167.

${ }^{56}$ v. R. Doran, The martyr ..., în G.W. Nickelsburg \& J.J. Collins, Ideal Figures ..., p. 217 u.

${ }^{57}$ M.F. Baslez, Persecuţiile..., p. 167.

${ }^{58}$ Sf. Ioan Gură de Aur, Omilia I la Sf. Macabei ..., în Predici ... (PSB 14), p. 447. 
bucurie" ${ }^{59}$. Credinţa în viaţa de apoi îi va face pe mulţi creştini să fie adevăraţi luptători în încercările, greutăţile şi chiar acceptarea morţii ${ }^{60}$.

În panegiricile închinate mucenicilor, speranţa în răsplata viitoare este exprimată prin metafore, care vorbesc de o adevărată încoronare. Imaginea coroanei ca simbol al nemuririi, corolar al laurilor, cu care se încununau atleții victorioşi, revine de nenumărate ori. A fi încununat înseamnă că eşti victorios, aşa cum astăzi, la alt nivel şi pe alte paliere, tinerii sportivi sunt încununaţi. Modelul rămâne, chiar dacă victoria sau biruinţa celor de azi este de altă factură. Dacă atunci biruinţa mucenicilor nu era vizibilă în arenă, ci reală în cealaltă lume, valoarea ei nu era mai puţin apreciată de Biserică. Mediatizarea valorilor, şi atunci ca şi acum, este o necesitate misionară şi pastorală.

În Omilia despre martirul Iulian ${ }^{61}$, Sfântul Ioan Gură de Aur foloseşte aceleaşi metafore, care reflectă opoziţia dintre recompensele pământeşti şi cele cereşti:

„Atleţii de la luptele din stadion luptă, înving, sunt strigaţi şi încununaţi în acelaşi stadion; cu atleţii credinţei nu-i aşa: ei au luptat în veacul de acum şi sunt încununaţi în veacul viitor; s-au luptat aici cu diavolul şi au învins, dar sunt strigaţi (aclamaţi) dincolo" 62 .

La fel a făcut şi Sfântul Vasile cel Mare, care într-o cuvântare de laudă la martirul Gordius opune, în mod sistematic, bunurile ce vor veni pedepselor imediate ${ }^{63}$.

Modelul de suferinţă în încercări şi suplicii ale martirilor este, pentru Sfinţii Părinţi, ocazia de a-i îndemna pe credincioşii Bisericii săi imite pe aceştia în viaţa lor religios-morală ${ }^{64}$. Martirul este model şi

\footnotetext{
${ }^{59}$ Ibidem, p. 449.

${ }^{60}$ V. Saxer, Bible et hagiographie. Textes et thèmes bibliques dans les Actes de martyrs autentiques des premiers siècles, Berne, 1986, p. 231-237.

${ }^{61}$ Sf. Ioan Gură de Aur, Predici ... (PSB 14), p. 506-517.

${ }^{62}$ Ibidem, p. 507.

${ }^{63}$ v. F.X. Druet, Langage, images et visages de la mort chez Jean Chrysostome (collection d'études classiques 3, Faculté universelle Notre-Dame de la Paix. Bibliothèque de la Faculté de philosophie et lettres 74) Namur, 1990, p. 228.

${ }^{64}$ v. R. Ziadé, Les martyrs ..., p. 281.
} 
pentru obţinerea biruinţei asupra patimilor sau pasiunilor acestei lumi. Viaţa virtuoasă are aceeaşi valoare ca şi martiriul. Clement Alexandrinul ${ }^{65}$ ne spune că orice credincios care ascultă şi împlineşte poruncile este un „prieten al lui Dumnezeu”. Origen vorbeşte în Índemn la martiriu despre o dispoziţie sinceră a sufletului, ca valorizare a poruncilor divine ${ }^{66}$.

Exemplul Macabeilor este folosit de Sfântul Ioan Gură de Aur ca temă pentru stăpânirea patimilor şi căutarea virtuţii.

Şi Sfântul Grigorie de Nazianz, în introducere la Cuvântarea a $X V-a$, vorbeşte despre raţiunea care stăpâneşte peste pasiuni şi coordonează cele două înclinaţii, ale virtuţii şi păcatului ${ }^{67}$.

Exemplul Macabeilor este pentru noi, zice Sfântul Ioan, „un îndemn neîntrerupt pentru dispreţuirea necazurilor şi a suferinţelor", iar în lupta noastră cu ,patimile păcătoase, mânia, pofta de averi, de trupuri, de slavă deşartă şi de toate celelalte asemănătoare să arătăm tot atâta răbdare câtă filosofie au arătat aceștia"68.

Plecând de la aceste exemple putem vorbi de o valorizare a exemplelor biblice sau patristice pentru tinerii de azi.

Am să mă opresc asupra a două referinţe din spaţiul cultural imediat.

Un mare regizor rus şi în acelaşi timp mare în spaţiul european și chiar mondial a scris o carte. E vorba despre Andrei Tarkovski ${ }^{69}$. Într-o mărturie pe care o face el scrie: „Absolutul poate fi atins numai pe calea credinţei şi a Creaţiei. Singura condiţie a luptei pentru propriul drept de a crea sunt credinţa şi propria predestinare, disponibilitatea de a munci şi intransigenţa. Creaţia are într-adevăr nevoie, din partea artistului, de „moarte la modul serios” (Boris Pasternak), în cel mai

${ }^{65}$ v Clement Alexandrinul, Scrieri, partea a II-a, Stromate (PSB 5), Bucureşti, Edit. IBMBOR, 1982, p. 276 u.

${ }^{66}$ v. H. Crouzel, Mort et immortalité selon Origène, I-III, Bulletin de littérature ecclésiastique, 79, 1978, p. 36-37.

${ }^{67}$ v. R. Ziadé, Les martyrs ..., p. 282-283.

${ }^{68}$ Omilia I la Macabei ... în Sf. Ioan Gură de Aur, Predici ... (PSB 14), p. 449.

${ }^{69}$ v. Andrei Tarkovski, Sculptând în timp, Bucureşti, Edit. Nemira, 2015. 
tragic sens al cuvântului. Scopul artei este acela de a-l pregăti pe om pentru moarte, de a-i curăţa şi de a-i afâna sufletul, de a-l face să devină mai bun" "70. Iată câteva identităţi de ideal şi valoare cu Sfântul Ioan Gură de Aur şi cu actualitatea Bisericii.

Un film apărut de curând, The Big Shot, tradus (în româneşte „Brokerii apocalipsei”), în regia lui Adam McKay, prezintă, referinduse la criza din 2007-2008, modul cum marile şi complicatele formule financiare de pe Wall Street sunt transformate aici în emoţie şi în fapt artistic. Dar nu pentru calităţile sale cinematografice am făcut referinţă la această peliculă, ci pentru o secvenţă în care un personaj din film foloseşte un citat care zice: „În secret, toată lumea aşteaptă să vină sfârşitul". Adică lumea s-ar comporta ca şi cum ar vrea să vină odată sfârşitul. Şi de aici putem trage o concluzie, sau mai multe. N-ar trebui să ne comportăm unii faţă de alţii, sau în adâncul inimii noastre, ca şi cum ar conta doar aceasta: sfârşitul lumii. Nu trebuie să fim nici destructivi, nici autodestructivi. Învăţăm şi din trecut şi din prezent şi transmitem această învăţătură urmaşilor noştri, aceea de a fi responsabili şi valoroşi pentru trecut, prezent şi viitor. Sau cum spune întâistătătorul Bisericii noastre: „Să încercăm să fim statornici într-o lume schimbătoare. Aceasta este cea mai mare virtute a unui credincios" $"$.

\section{Concluzii}

Un exemplu biblic preluat şi amplificat de un Sfânt Părinte are reverberaţii până în antichitate. Atât civilizaţia iudaică cât şi cea creştină pun un accent deosebit pe educarea celor tineri şi pe încercarea de a le inocula acestora tradiţiile şi exemplele cele mai elocvente ale înaintaşilor.

\footnotetext{
${ }^{70}$ Ibidem, coperta a IV-a.

71 Cuvântul P.F. Daniel, Patriarhul Bisericii Ortodoxe Române la deschiderea sesiunii Adunării Naţionale Bisericeşti, 24 februarie 2016.
} 
Sfântul Ioan Gură de Aur a realizat cât de importantă este formarea încă de tânăr; ideea de popor dreptmăritor centrat în jurul ideii de memorie textuală biblică şi zicem noi patristică.

Învăţătura pentru tineri o realizează Sfầntul Ioan prin tensiunea poetică a cadrelor din Omilii I şi II despre Macabei. Există o densitate emoţionale în imaginile transmise prin cuvânt. Şi pentru orice tânăr densitatea nu stă în simboluri cifrate, ci într-o stare de spirit pe care o resimte venind direct spre el dinlăuntrul cadrelor prezentate cu elocvenţă. Chiar dacă vorbeşte de suferinţă sau martiriu, rolul predicii, în concepţia Sfầntului Ioan, nu e acela să te pregătească pentru moarte, ci pentru viaţă, şi încă o viaţă plină de nobleţe şi plină de valoare într-o comunitate de credinţă.

În mod surprinzător pentru noi, modernii, studiul fenomenelor de persecuţie şi interdicţie, ar putea fi citit ca un marş spre intoleranţă, ca o înfruntare a pluralismului. Învăţăm din aceste exemple ce trebuie să ne pronunțăm în favoarea unei întrepătrunderi tot mai accentuate a religiosului cu universul social-politic, fără ca să ne pierdem identitatea creştină. Martiriul a fost $\mathrm{o}$ atitudine de excepţie. A fost o alegere minuţioasă care n-a mai putut fi susţinută când comunităţile au evoluat într-o Biserică a mulţimilor. Nu poate fi tăgăduit faptul că mărturia spectaculoasă a martirilor a dat o primă vizibilitate unei religii care se năştea. Eficacitatea figurilor şi povestirilor în mediatizarea mesajului creştin ţine de înrădăcinarea lor foarte precisă şi de semnificaţia lor universală.

Desigur că e foarte greu ca învăţătura şi limbajul primelor veacuri creştine să găsească ecou în sufletul tânărului sedus de gadgeturi. Dar nu este înţelept a refuza întâlnirea cu Dumnezeu pe motiv că nu se încearcă mai des un up date al învăţăturilor Sfinţilor Părinţi. În ce constă prospeţimea lor ne-o arată Sfântul Ioan Gură de Aur: a merge spre alţii, adică a nu fi o Biserică închisă; a manifesta şi a răspunde milosteniei lui Dumnezeu; a câş̧iga încredere în Biserică, diminuată din cauza păcatelor fiilor ei; a folosi un limbaj atrăgător şi frumos. Şi atunci Dumnezeu ne va da biruinţa, pentru că tinerii au ştiut să sufere. 